\section{SCIENCE AND SOCIETY}

\section{By DR. F. SHERWOOD TAYLOR \\ Museum of the History of Science, Oxford}

$\mathrm{A}^{\mathrm{T}}$ $T$ the twenty-first annual general meeting of the University Catholic Federation of Great Britain, which took place at Birmingham during April 10-12, three conferences were held on the theme of "Science and Society". The first conference was concerned with the question, "What is Science?", and under the chairmanship of Prof. Thomas Bodkin, professor of fine arts in the University of Birmingham, was opened by a paper from Dr. F. Sherwood Taylor, curator of the Museum of the History of Science of the University of Oxford, entitled "An Historical Survey of the Rise of Science".

Dr. Sherwood Taylor pointed out that the rise of science was contemporary with that of civilization. Its first stage was the rational treatment of crafts and the study of phenomena which had religious significance. The Egyptians and Chaldeans were the chief originators of science in its practical aspect, but theoretical science, the philosophy of Nature and natural causes, had to await the genius of Greece, which excelled in the abstraction of general principles, yet was defective in its rash assumption of a universal correspondence between that which the mind conceived as fitting and that which in fact existed. The Greeks, and the immediate heirs of their achievement, excelled in all which could be investigated geometrically, but were comparatively deficient in those sciences which could be acquired only through the discipline of the laboratory, which began to have importance only when the wave of ancient science was fast receding. In the period A.D. 300-1100 Europe was barren of scientific achievement, because wholly preoccupied with political reconstruction, and with the enormous implications of the central fact of human history, the Incarnation. The attitude of this period towards natural science was that speculation with regard to it in no way furthered a blessed life, and so was a culpable waste of time and talents. Meanwhile, the philosophy of Greece blossomed again in Islam, and when it came to Western Europe and was assimilated with Catholic doctrine, Greek science came with it. In the thirteenth century such men as Albertus Magnus, Roger Bacon, Peter Peregrine, Mondino, and the numerous alchemists gave good hope of an age of experimental science. But it was not to be, and the wave of modern science which is yet gathering force took rise from a different source, the Platonic speculations of such men as Marsilio Ficino.

After a century or more, when science was regarded, with natural magic, as an arcanum, the genius of Galileo demonstrated the practice of modern science, while Francis Bacon enunciated its theory. Here came perhaps the most portentous step in world history, the separation of natural knowledge from philosophy and religion. Natural knowledge, by limiting its objective, became cumulative, and ever more swiftly grew to its present bulk. The economic application of science, previously unimportant, became finally predominant. Industrial civilization led to the horrors of exploitation in the nineteenth century, and each succeeding half-century has brought to mankind a more numerous crop of revolutionary inventions. The next half-century is likely to transform the world even more profoundly than the last, for good and evil : Are we to let it proceed without rational direction or control ?
The second paper in this conference was given by the Rev. J. Leycester King, S.J., professor of psy. chology at Heythrop College, who took for his subject "Science and Reason". He emphasized that a large part of the world's troubles can be traced to a desertion of scientific ideals, the substitution of illusion for fact. Science is alive to the discord and irrationality of the modern world, and to the implications of the policy of tampering with truth, which policy is the antithesis of science. Yet most of those who seek a remedy in science are themselves, consciously or unconsciously, subject to the illusion, long discarded by philosophy, that only what is modiately or immediately observable is real. Science must realize that there are unobservables which are real, and which are within the competence of human thought to study and systematize. These matters are now reserved to philosophy and theology. Science, divorced from these, has made rapid progress, it is true, but this progress has only been possible because science and its workers are embedded in a civilization based upon Christian principles. The knocking away of the Christian foundations of our civilization has already resulted in self-deception, illusion, wishful thinking and unreason, and though we may point in priggish horror at the deliberate distortion of truth practised by our enemies, we are not to forget that we are ourselves already far down the slope of disintegration.

We have been living on our spiritual capital. Our need is not of more science, or of less science, but of formulating an end and meaning of life, perceiving a unity in which the harmony of the manifold appears. Our knowledge of this unity will but increase the purity and vigour of science, for the truth inherent in the whole must subsist in the subwholes which form our field of investigation. Science must be re-married to philosophy, which alone can provide a datum-line of immutable principles, about which oscillate the dogmas of science, of which so many have been proclaimed as infallible, thea modified, and at last abandoned. Separated, philosophy and science must fade and pine: united they have the grandest of futures.

The second conference, under the chairmanship of Dr. Hugh O'Neill, chief metallurgist of the London, Midland and Scottish Railway, was concerned with the social impacts of science, and was opened by Prof. Louis Renouf, professor of biology at University College, Cork, with a paper entitled "The Influence of Modern Biology". Modern biology, he indicated, begins with Darwin, and since its inception has exerted the most conspicuous influence on human thought. Darwin's notion of organic evolution was intended to be, and in fact proved, a most valuable working hypothesis for science, but in the able hands of T. H. Huxley, and later as "travestied by Haeckel", it became the foundation of the materialistic biology which has vastly influenced the popular beliefs of the modern world. Biology and physiology have entered the field of human behaviour; the attempts made to account for moral codes in terms of endocrine glands are good examples of their more extreme methods. To-day social biologists have enormous prestige and popularity, and problems of human society have come to be thought of in biological terms. It is of the greatest importance, then, that the biologist should be fitted for his present responsibilities. But, in fact, the greatest part are reared in a materialistic atmosphere, and acquire a philosophy which is manifest in the 
first-class research work which is to-day being presented in an irrelevant matrix of Marxian philosophy. Catholics, and indeed Christians in general, are at fault in looking upon all forms of science with a timidity that is a relic of a past defensive attitude. There is a great need for more Christian men of science, especially biologists, who may oppose a truly personalist attitude to the decadent views falsely put forward as the answers of science to the human problems of marriage, education and family relationships. One of the most important steps to be taken is the proper education of medical men. The medical course is long, and commonly admits of few but professional studies, whereas it is most desirable that medical men should have some knowledge of sociology, the arts and the elements of philosophy. A preliminary year's course of humanistic studies would be of great value to men who will have so important a position in the social structure.

There followed a paper on "Science and Man" by Dr. H. P. Newsholme, professor of hygiene in the University of Birmingham. The most important effect of science on the community was its example of single-minded search for truth, and discarding of emotional and personal feelings; but this setting aside of all but the material aspect of things, though it arise from a recognition of the incapacity of science, may lead to the implicit assumption that the material aspect alone is worthy of consideration. This limitation of outlook has led to correspondingly defective results. Thus Freud did good service in opening up the subconscious, but failed to recognize in it an avenue of God's approach to man. In the region of the physical life and of social environment the debt of humanity to science has been incalculable. But though the health and comfort of man has been increased, the troubles of his spirit are left untreated.

The great prestige of science has led society to respect the opinions of its workers, and their implicit materialism has contributed to the formation of a materialistic society, which in turn rears more materialistic scientific workers. Not only science, but also almost every human activity, has become dissociated from religion, and the immediate consequence has been their exploitation by the selfish. Scientific agriculture has led to denudation and sterility; family limitation is depleting the population and degrading it by separating the pleasures of sex from its responsibilities. Furthermore, the exaltation of the physically fit as alone worthy of survival threatens the world with the arrangement of mating on physical grounds, with sterilization of the so-called unfit, and with euthanasia, which leads by a short step to the deliberate 'elimination' of the aged, mentally deficient or incurable. In the realm of ideas the effect has been even to extend natural law beyond its function, which is the summation of past events. Such events as find no place in the records of science, for example, miracles, such as the Resurrection, the greatest of them, are sometimes denied; and theories, such as that of organic evolution, are extended from body to mind. If science had retained its association with religion, it might have grown more slowly, but the product would have been richer and more significant, and the world would have been protected against the worst types of exploitation of the powers of science.

The final conference was presided over by the Right Rev. Bernard Griffin, Bishop Auxiliary of Birmingham. The Rev, Philip de Ternant contributed a paper on "The Place of Science in Educa- tion". His title, he said, was not science in the school, which is another subject. At the time of Alcuin the concept of a scholar was primitive but comprehensive. The old Trivium and Quadrivium contained the germ of scholasticism and of universities : it involved recognition of the unity of the universe and of the spirit of man. One idea may be seen to underlie these three forms of a single word. As material knowledge increased, specialization became necessary, but to-day's is much overdone in response to the utilitarian age. Our task is to create a reversion to the older type of scholar and to re-integrate the scattered elements of knowledge, now known only collectively as science. The great specialists are noteworthy for the breadth of their basic knowledge, but men of science generally lack philosophy to-day. The true purpose of a university has been disnatured by fetishes, popular and scholastic. The width of outlook and general interest formerly displayed in the older "Academes", from the Royal Society down to local field clubs, and in the followers of nature hobbies in the family circle itself, is much needed to-day.

The Rev. Philip de Ternant advocated the 'perennial' philosophy of St. Thomas Aquinas and his modern followers, such as Maritain, in opposition to the widespread aberrations of to-day, and asked for a primer or handbook on the subject adapted to the use of science students. He regretted the obscurantism of the public and of certain pious people. St. Thomas had established that the study of natural science is a religious duty, as leading us, first to consideration and admiration of the Divine.Wisdom, thence to reverence, fear and especially love, when the goodness and beauty of created things attracts the souls of men and leads to a comparison of the same things in a higher form in God; finally it sets up in men a certain similitude of the Divine perfection and wisdom. So, also, a wrong notion of the nature of creatures leads us to think they are all that exists, and that men are subject to laws which do not exist. So, argues St. Thomas, that opinion is false which says that it matters nothing to religious faith what anyone thinks of creatures, so long as he is right with God; for error concerning creatures leads to a false idea of God, and so leads minds away from Him. Therefore scripture threatens with penalties, as if they were pagans, those who have a false idea of natural facts: "Because they have not understood the works of the Lord, and the operations of his hands : thou shalt destroy them and shalt not build them up" (Ps. xxvii, 5).

\section{QUANTITATIVE AND QUALITATIVE METHOD IN SOCIOLOGICAL RESEARCH}

$\mathrm{T}$ HE principal item on the Saturday (April 11) meeting of the British Psychological Society at Brighton was the open discussion in the evening between Mr. Henry Durant of the British Institute of Public Opinion, and Mr. Tom Harrisson of MassObservation. Mr. Durant opened the discussion by supporting the proposition "that Empirical Methods in the Social Sciences should be Predominantly Quantitative".

Social scientists should, in their empirical work, 